(104)

肺炎双球菌の胆汁並にベニシリン耐性怢の性狀について

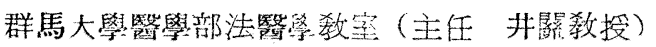

岡田正次勘 - 由尾哲夫

肺炎双球菌の胆汁溶解性は肺炎双球菌、特異 な現象として既に知られているがこの感受性 の高い菌を胆汁の入つたブイヨンに培養し, 胆 汁の低濃度より次第に高濃度のもの八植えつぐ

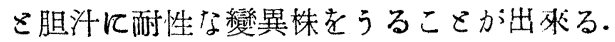

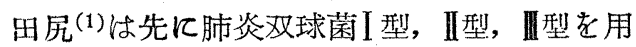
いて以上の方法により10\%の割合に牛胆汁を含 むブイヨンに發育し得る耐性株やつくり，異性 型物質より見た抗原構造上に原株飞耐性株との 間に著明な變化の起きること学明らかにした。

义一方, 肺炎双球菌はペニシリンに對してを 胆汁の場合と同樣の方法によりペニシリン而性 株に變異するのであるが.このペニシリン耐性 株の生物學的並に免疫學的性狀につんては隓に 河野(2)，芳村 ${ }^{(3)}$ ，中村(4)等の報告がある.

われわれは, 牛胆汁並にペニシリンに對して 丸なり高度の耐性株について，その生物學的性 狀特に糖分解能の變化, 及び牛胆汁並にペニシ リン耐性怢の相互間の感受性等について調べた

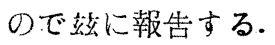

\section{實驗材料及び實驗方法}

1. 實験に使用した肺炎双球菌型S型のI型,

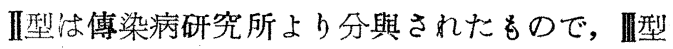
は當敎室に於て患者より分離したものである。

2. 胆汗耐性怢は, 各型のS型或はR型を最初 牛胆汁の $0.25 \%$ 割合に入入つた馬肉ブイョンに 培養し每日植えつぐを同時に次第に牛胆汁の漫 度を高わ，10\%に加えても生えうる程度に變異 させたものである.

3. ベニシリン耐性株は肺炎双球菌四型のS型 を牛胆汁の場合飞同樣の方法により,ペニシリ ン加血清ブイョン中を 150 代通過させたるので, 原株に比し約200倍耐性が强まつている。

\section{實 驗 成 績}

\section{A 胆汗耐性株の性狀}

(1) 形態及び集落.

I型，I型，回梨の年胆汁耐性株は各型のS型， $R$ 型，に比して連鎻高長く，血液寒天平板上の 集落の大さは[型，II型の耐性株は各々の R 型上 り稍小さく、これ反反して四型の耐性株はかえ つて稍大きく，各型をも耐性怢の集落け $\mathrm{R}$ 型上 り不透明で表面が粗造である.ブイヨンに酸育 させると耐性怢は一般に沈澱性の發育走示して レる.

（2）自發凝集性

生理的食塩水に對して型, II 型の耐性怢は, $\mathrm{S}$ 型, $\mathrm{R}$ 型と異なり自發凝集性存しているが, 正型の耐性怢には I 型, II型に比して弱い自發凝 集性を認めた。

〔3）マウスに對する表力

体重 1 g $\mathrm{g}$ 冈外のマウスを選び，ブイヨン20時 間培養の生菌支その腹腔內に接種し1週間觀察 した後，M. L.D. を決めた。これによるを 肺炎双球菌のR型は各型の間に大差なく 0.5-1. Uceであるが，耐性株はR型より多少毒力は低下

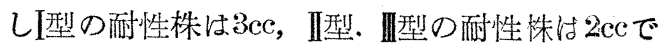
あつた。

\section{(4) 耐性の復歸}

各型の胆汁耐性株を血液寒天平板に培養し 100 代以上代を重ねたか胆汁に對する耐性には全く 變化が認められなかつた。即ちこの牛胆汗耐性 株は一種の突然變異を起しているものと考えら れる。

\section{（5）糖分解能}

表1に示す如く各型のS型モR型の間には糖分 解能に變化は認められないか，而性株になると 新たにマンニット走分解なるようになる。 又四 型はS型，R型共にイメリン分分解するが，耐性 
株はこの性狀を失なつている。

表 1 肺炎双球菌のS 型, R型及び牛胆 汁河性株门糖分解能

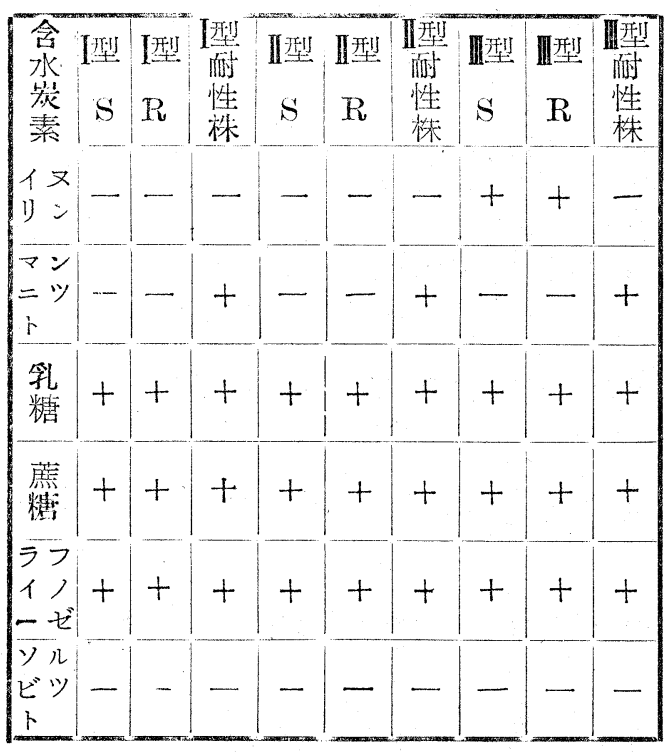

表 2 肺炎双球菌のS 型、R型及び牛胆 汁耐性株のペニシリン感受性

\begin{tabular}{|c|c|c|c|c|c|c|c|c|c|}
\hline$\left\{\begin{array}{l}0 \\
y \\
0 \\
u / c c\end{array}\right.$ & $\begin{array}{l}\text { 型 } \\
\mathrm{S}\end{array}$ & $\mid \begin{array}{c}\text { 型 } \\
\mathrm{R}\end{array}$ & $\begin{array}{l}\text { I型 } \\
\text { 牛胆 } \\
\text { 汁耐 } \\
\text { 性株 }\end{array}$ & $\begin{array}{c}\text { II型 } \\
\mathrm{S}\end{array}$ & $\begin{array}{c}\text { I型 } \\
\mathrm{R}\end{array}$ & 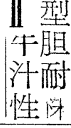 & $\mid \begin{array}{c}\text { 型 } \\
\mathrm{S}\end{array}$ & $\begin{array}{c}\text { 而型 } \\
\mathrm{R}\end{array}$ & 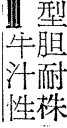 \\
\hline 0005 & + & + & + & + & + & + & + & + & + \\
\hline 0.01 & + & - & + & - & - & + & + & + & + \\
\hline 0.02 & - & - & + & - & 一 & + & - & - & + \\
\hline 0.05 & - & - & + & - & - & - & - & - & + \\
\hline 0.1 & - & - & - & - & - & - & - & - & + \\
\hline 0.2 & - & - & - & - & - & - & - & - & - \\
\hline 0.5 & - & - & - & - & - & - & - & - & - \\
\hline 1.0 & - & - & - & - & - & - & - & - & - \\
\hline
\end{tabular}

十は菌の發育を示す
（6）牛胆汗耐性株のペニシリンに對する感受性 表 2 亿示す如く各型のペニシリンの最少有效 濃度はS型に於てば $0.01-0.02 \mathrm{u} / \mathrm{cc} て ゙$ 型 $8 \mathrm{R}$ 型 及び各型の間に大差はないが，牛胆汁耐性株は 0.05-0, 2u/ceで型はR型に比して10倍，型は R型に比して4倍, 目型はR型に比して10倍ぺニ シリン耐性をなつている.

B ペニシリン酎性怢の性狀

（1）形態及び集落

酎性株は原株に比して菌体は大きくグラム染 色の陰性化も認められる. 集落は小さくなり粘 液產生は原株に比して著明に減少している。

（2）マウスに對する毒力

而性株の毒力は著明に低下し，原株のM. L.

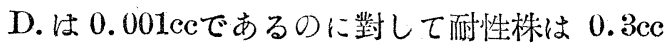
であつた。

(3) 耐性の復歸

ペニシリン耐性の復歸は耐性が5倍位までは ブイヨン又は血液寒天に5〜 6代うえつぐことに より容易に復歸するが10倍位になると復歸は困 難となり，150代通過させた附性株では血液寒 天に 1週間間隔で75代うえついでも耐性には殆 んど變化が認められなかつた。

（4）糖分解能

イヌリン、ンニット，乳糖，蔴糖，ラフィ ノーゼ, ソルビット等について原株と耐性株と の糖分解能を比較してみると, 而性株は蔗糖の 分解能を失つていた. この䓞糖の分解能の消失 はペニシリン培地を8代通過させて为認められ るもので，この程度のペニシリン通過では耐性 は原株に比し約 2倍であり比較的容易に耐性は 復歸するが蔴糖の非分解性には變りはない，又 この8代ペニシリン通過株をマウスの通過を3代 行つてを分解能は得られなかつた。

（5：ペニシリン而性株の牛胆汗に對する感受性 ペニシリン耐性株は原株に比し牛胆汗に對し ても耐性が强まつている. 即ち原株が $0.25 \%$ 胆 汁加ブイヨンにかろうじて生えうるに對してぺ ニシリン耐性株は $0.75 \%$ の胆汗濃度に於てる發 有するのが認められる。 
(6) S-R變異

ペニシリン耐性株は血液寒天平板上で策落は 小さく粘液座生が惡心のでR留に似に外情：是 しているが，抗S血清の中型の凭誛血清にいる 特異的に㠜集し, 且 S.S.S. の產生弱いなが

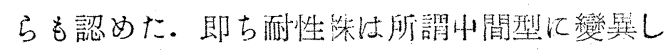
たものと考えられる.この点牛胆汁耐性恘仕ぺ ニシリン耐性格と筫なり, 酎性う; 8倍位强吉る

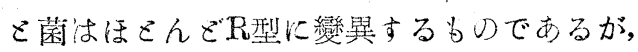
ペニシリンに於ては200偣耐性に變翼しても完 全なR型の出現け認められなかつた。

\section{考察並に總括}

以上の成績より肺炎双球菌Ｉ型，几型，圆型ひ斗 胆汁洏性株忛集落形態, 自發凝集性, ブイヨン の發育狀况等上り Griffith》言うR型ょりとと, むしろその後Dawsonによつて發表されたMーS一 $\mathrm{R}$ 三相變異說のさ型に似に性狀在示している.然 しながら午胆汁耐性株はその由來によつて明ら かな如く胆汁に著明に耐性であり，不可逆性の 變異株であるこを等より DawouDR型と異な る别の變異型式であると考えられる。この變異 型式に閵連した他の性狀の變化こしてマンニッ 卜分解能考新にに獲得しているのは代謝機㩐の 變化つ一端を知る興淕ある知兒である。

肺炎双球囷面型つペニシリン驸性怢に，その 菌形, 集落形態, 毒力, 附性の不可逆性等に於 て河野(2)，芳忖(3)，等の報告に略一致した成䋶 を示している.又ペニシリン酎性洙は装糖の分 解能を失つているが，これ触糖分解能の變化が ペニシリン耐性と何等かの關連性があるるのと 考えられる。

牛胆汁及びペニシリン耐性株の泪互間の感受 性を交叉試験により比較すると，牛胆汗耐性株 はペニシリンに對して原株に比し5-10倍耐性で ありペニシリン耐性株は牛胆汁に對し原株に 比し約3倍酎性であつた

$$
\text { 文 献 }
$$

（1）田尻哲夫：肺炎双球菌の異性型物覧の 變異、第33次 日本法醫學總會會誌. 日本法醫 學雜誌，3 (4-3)，224，9 昭24. (19).（2)
河野久米雄：ムコズス菌のペニシリ:夜びス トレブトマイシンに對する感性. 酎性並びにそ の後歸に就いて、ペニシリン，3(1)，59-60， 昭36. (1949). (3) 站村次雄 : 細菌のぺ二 シリン耐性に關する研究。北海道醫學雓誌, 听 (4), 169-172, 昭24. (I949). (4) 中村䁷, 山日守英 : 細菌のペニシリン耐性について.

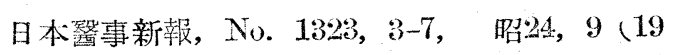
49). (5) Griffith, F. : Report of Public Health and Med. Subj., Lomk., No. 18,19 23. (6) Dawon, M.H. : Variation in the pheumococcu:. J. Path. \& Bact., 39, 323$3 \pm 4,193 \div$ 


\title{
ON THE CHARACTERS OF BILE-RESISTAND AND PENICILLIN RESISTANT-STRAINS OF PNEUMOCOCCI.
}

\author{
Shojiro Okada, Tetuo Tajiri \\ Departnent of Legal Medicine, School of Medicine, \\ Gumma University. (Director:Prof.S. Iseki)
}

\begin{abstract}
We prepared highly bile-resistant strains of pneumococei type I, II, II, and a highly penicillinresistant strain of pnetmococcus týe $\mathbb{I l}$, and investigated changes of their characters comparing them with the parent strains.
\end{abstract}

(1) The bile resistant strains resemble to Dawson's $R$ int heir colonial roughness, granular growth in fluid media, and instablity insaline, but they are different from Dawson's $R$ in their bile resistance and irreversibillity to $\mathrm{S}$.

(2) The bile-resistant strains are capable of fermenting mannitol.

(3) The penicillin-resistant strain of pneumococcus tyle ll loses the power to ferment saccharose

(4) The bile-resistant strains are five to ten times as resistant to Fenicillin as their farent strains, and the penicillin resistant strain is three times as resistant to bile as its parent strain. 